\title{
Field Performance Evaluation of a Combined Cultivator Developed at Kenana Sugar Company-Sudan
}

\author{
Mohamed H. Dahab ${ }^{1 *}$, Mohamed H. Numan² and Omer A. Abdalla1 \\ ${ }^{1}$ Dept. of Agric. Engineering, Faculty of Agriculture, University of Khartoum, Sudan \\ ${ }^{2}$ Kenana Sugar Company, Sudan
}

*Corresponding author details: Mohamed H. Dahab; mhdahabahmed55@yahoo.com

\begin{abstract}
Sugar cane production requires a number of operations to be carried out in the field through number of implements and machines. Therefore, time consuming and required large amount of energy. A combined field cultivator was designed in Kenana agricultural implements factory (KAIF) to carry out at one time multi operations, cultivation, furrow-reforming and Fertilizer placement. This is to increase field productivity, reduce farm power and lower operation time and cost. The combined implement was evaluated in Kenana cultivation fields and compared with the three individual implements, rigid tine cultivator, furrow reformer and fertilizer applicator. The measured parameters were drawbar pull, power requirements, field capacity, fuel consumption and total time in the field. The results showed highly significant differences at $1 \%$ level between the different implements for the field capacity, fuel consumption and significant differences at $5 \%$ for the drawbar pull. Power requirement in $(\mathrm{kW})$ for the combined cultivator was $77 \%$ of those individual implements. Total time per feddan to accomplish the required operations by the combined cultivator was $57 \%$ of that required by the individual implements. Fuel consumption was reduced to $57 \%$ when combined implement was used compared to that consumed by individual implements. It was concluded that the combined cultivator was effective in increasing field productivity and reducing power and cost of operations.
\end{abstract}

Keywords: cultivator; rigid tine; furrow reformer; sugar cane; Kenana

\begin{abstract}
INTRODUCTION
Farm machinery management deals with the optimization of the equipment used for agricultural production; it is concerned with efficient selection, operation, maintenance, and replacement of machinery. Farm machinery selection is fundamental in achieving the concept of sustainable agriculture, which becomes a global issue in agricultural sector development [1]. Proper management and selection of implement contributes greatly in reducing cost and difficulties in field operations, maximize production and also protects the environment against pollution.
\end{abstract}

Sugar industry in Sudan, started in the sixties and reached its present size in the eighties. Sugar industry has a significant contribution to the national income and the economy of the country. Sugar cane is now grown in the central clay plains and the expansions in this region depend on the suitable soil and availability of irrigation water and machinery. The production of sugar cane involves many operations from planting to harvesting. It is produced either by planting stalks of cane or by ratoon. [2] considered the following operations as common practices in sugar cane field; uprooting, by chisel, disc or shape ploughs, harrowing, with discs or tines to form a suitable seedbed. Planting depth of $8 \mathrm{~cm}$ was recommended in sandy soils and found that depth was not so important in heavy cracking soils [3]. It was reported that when the plant is about three months old, soil should be transferred from the inter-rows to the planting rows so that the plant gets better anchorage and resistance to lodging [4]. The practice is necessary for mechanized harvesting operations [5].

The concept of combined implement was found to be of great importance to carry out more than one operation at the same time and to conserve energy and time and to save labour cost. Some pioneer studies were carried out to combine tillage implements with planting machines as a minimum tillage combined system [6], [7] and [8]. It was found that combining tillage tools in two types of soils resulted in saving about $44-55 \%$ of the cost and $50-55 \%$ of the time [9]. A combined chisel-planter was described as a minimum tillage implement, for reducing erosion [10]. The minimum tillage system was developed by combining through successive practical work (a chisel plow, fertilizers applicator and seed drill). It was classified as tillage planting machine. The interest for minimum tillage of seeding involve saving time and energy. He also concluded that the chisel -planter used $70 \%$ less fuel, and $49 \%$ less time per acre than conventional system. [11] stated that the combination of a rotary tiller and pneumatic seeder was found to be suitable for one-pass plow-seeding operation as a minimum tillage system for fuel and time saving. It was stated that the ridger- planter as one pass operating machine [12], the conventional mechanical system of planting (separate ridger and planter) was nearly double that of combined ridger-planter and field capacity of the combination was approximately double that of the mechanical 
double that of the mechanical system and twelve times the manual, which allows times saving and expansion of the cultivable area. An experiment was carried out to evaluate in the field the performance of chisel and ridger tillage implements combined into one machine [13], for unit draft, power, slippage, fuel consumption and time. The results showed that the combined implement reduced the unit draft by $26 \%$ compared to the individual implements. The power requirements and the total times were reduced by $49 \%$ and $47 \%$ respectively by the combined implement. A combination tillage implements composed of cultivator and disc harrow was developed and found that the overall performance index was higher for combination tillage implement as compared to that of individual tillage implements [14] and [15]. The main objective of the present study was to develop and evaluate a combined machine formed from three implements, rigid tine cultivator, furrow reformer and fertilizer applicator to increase field productively, reduce farm power and lower operational costs and time. Therefore, the specific objectives are:

- To evaluate the field performance of the combined machine compared to the individual implements.

- To measured and compare the parameters, field capacity and efficiency, fuel consumption and power requirement.

\section{MATERIALS AND METHODS}

\section{Experimental site and equipments}

The experiment was carried out at Kenana sugar cane fields. The soil of the area is classified as $15 \%$ sand, $22 \%$ silt, $63 \%$ clay (heavy clay soil). Kenana sugar company is $450 \mathrm{~km}$ south west of Khartoum, Latitude $13^{\circ} \mathrm{N}$ and Longitudes $30^{\circ} \mathrm{E}$.

Two Massey Ferguson tractors (MF440) were used for the experimental measurements and the specifications of the tractors are given in (TABLE 1). The implements used in this study were rigid tine cultivator, furrow reformer and fertilizer applicator (PLATE 1, 2, 3) and the specifications of these implements are shown in (TABLE 2). Chain- boltsstop watch- paper sheets- tape meter $(50 \mathrm{~m})$ - steel rodssteel container (4 gallons) - measuring cylinder (1 lit.) and dynamometer (50-300 KN) were also used.

\section{Experiment design and treatments}

Three cultivation areas were chosen randomly from seven cultivated areas in the scheme, then randomly a field was chosen from each area, (field area was 150-300 feddans). Three plots were designed in each field (beginning, middle and end of the field). The plot area was $\left(300 \mathrm{~m}^{2}\right)$ which is 2 furrows in width and 100 meter in length. This plot was equal to (0.07) feddan.

Four treatments were done in every plot for each implement (four implements) and repeated three times in every field ( 3 fields) this gives nine replicates and a total of 108 plots.

TABLE 1: Specification of tractors used on experiments

\begin{tabular}{ll}
\hline Item & Description \\
\hline Model & Perkins \\
No. of cylinders & 4 \\
HP & $82(61.6 \mathrm{KW})$ \\
Rev $/ \mathrm{m}$ & 2200 \\
Injection & Direct \\
Capacity & 4.1 lit \\
Aspiration & Natural \\
Steering & Hydrostatic \\
Max. engine torque & $288 \mathrm{NM}$ \\
Weight & $2665 \mathrm{~kg}$ \\
Length & $3.98 \mathrm{~m}$ \\
Width & $2.06 \mathrm{~m}$ \\
\hline
\end{tabular}

TABLE 2: Specifications of Implements

\begin{tabular}{|c|c|c|c|}
\hline Parameter & $\begin{array}{l}\text { Fertilizer } \\
\text { applicator }\end{array}$ & Ridger & $\begin{array}{l}\text { Rigid } \\
\text { tine }\end{array}$ \\
\hline Type & $\begin{array}{l}\text { Tractor } \\
\text { mounted }\end{array}$ & $\begin{array}{l}\text { Tractor } \\
\text { mounted }\end{array}$ & $\begin{array}{l}\text { Tractor } \\
\text { mounted }\end{array}$ \\
\hline \multirow[t]{2}{*}{ Lifting } & By Tractor & By & By \\
\hline & hydraulic & $\begin{array}{l}\text { Tractor } \\
\text { hydraulic }\end{array}$ & $\begin{array}{l}\text { Tractor } \\
\text { hydraulic }\end{array}$ \\
\hline Height & $1550 \mathrm{~mm}$ & $365 \mathrm{~mm}$ & $800 \mathrm{~mm}$ \\
\hline Length & $1110 \mathrm{~mm}$ & $980 \mathrm{~mm}$ & 1200 \\
\hline Width & $2480 \mathrm{~mm}$ & $1000 \mathrm{~mm}$ & $1800 \mathrm{~mm}$ \\
\hline Components & $\begin{array}{l}\text { Mild steel } \\
\text { frame, } \\
\text { 2hoppers, } \\
\text { transmission } \\
\text { system. }\end{array}$ & $\begin{array}{l}\text { Two } \\
\text { wings v } \\
\text { shape } \\
\text { frame, } \\
\text { cutting } \\
\text { edges }\end{array}$ & $\begin{array}{l}\text { Eight } \\
\text { shanks, } \\
\text { two raw u } \\
\text { shape } \\
\text { frame. }\end{array}$ \\
\hline
\end{tabular}

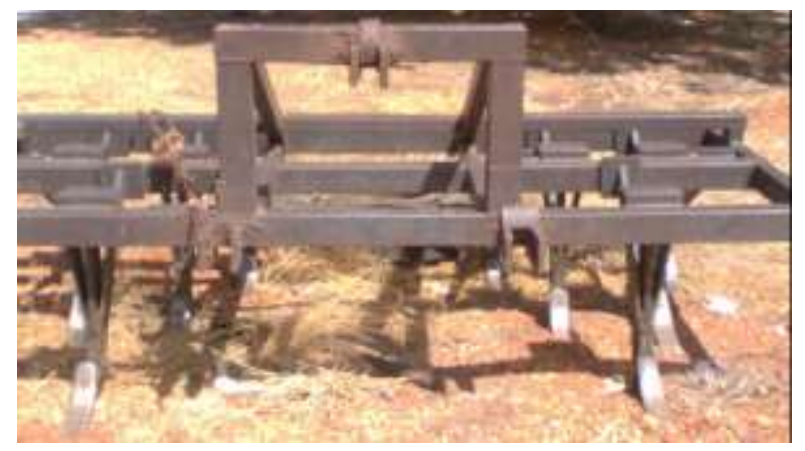

PLATE 1: Rigid tine cultivator

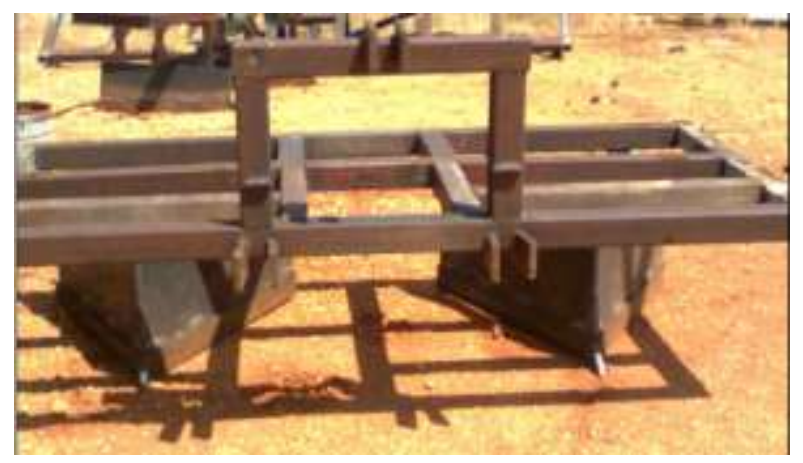

PLATE 2: Ridger

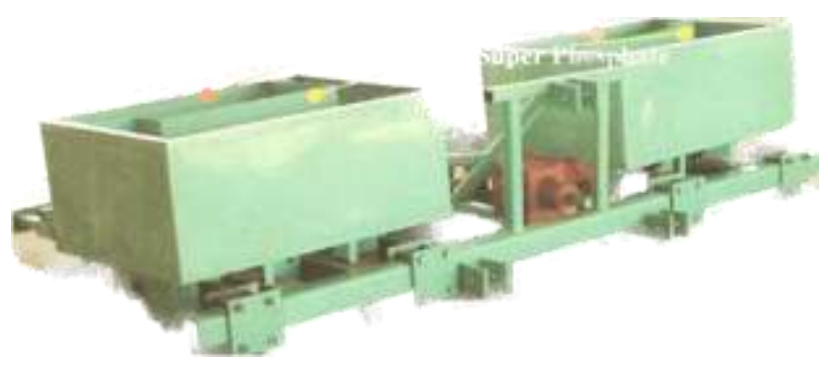

PLATE 3: Hoppers of fertilizer applicator

Field performance machinery measurements Effective field capacities (EFC) and field efficiency (FE) of different machines were calculated as follows:

(a) EFC (Fed/hr) = Total plot area $\left(300 \mathrm{~m}^{2}\right) \times(1 \mathrm{ha})$ Total Time to cover plot $(\mathrm{hr}) \times 4200 \mathrm{~m}^{2}$ 
(b) FE (\%) = Productive time (hr) $\times 100$ Total plot time (hr)

The fuel consumption rates (FC) in $\mathrm{L} / \mathrm{fed}$ and $(\mathrm{l} / \mathrm{hr})$ were calculated as follows:

$$
\begin{aligned}
& \text { FC }(\mathbf{l} / \mathbf{f e d})=\frac{\text { Reading of refilling cylinder }(\mathrm{ml}) / 1000}{\text { Plot area covered }\left(\mathrm{m}^{2}\right) / 4200} \\
& \text { FC }(\mathbf{l} / \mathbf{h r})=\frac{\text { Reading of refilling cylinder }(\mathrm{ml}) / 1000}{\text { Total time to cover plot }(\mathrm{sec}) / 3600}
\end{aligned}
$$

Measurement of each implement draw bar pull (draft) was calculated as follows:

Implement draft $(\mathrm{KN})=$ pull of tested tractor with implement (KN) - Pull of the same tractor only (KN)

The power exerted by the tractor on the implement was calculated using the following equationowe:

$$
\begin{aligned}
& \text { Dbp }=\frac{\text { DxS }}{3.6} \\
& \text { Dbp }=\text { Draw bar pr }(\mathrm{KW}) \\
& \mathrm{D}=\text { Implement draft }(\mathrm{KN}) \\
& \mathrm{S}=\quad \text { Forward speed }(\mathrm{Km} / \mathrm{hr})
\end{aligned}
$$

\section{RESULTS AND DISCUSSION \\ Description of the assembled combined field cultivator}

The combined field cultivator was developed as a two row cultivator, tractor mounted machine. It was designed to comprise functional components of a chisel cultivator furrower and a fertilizer applicator. (The specifications of this machine are shown in (TABLE 3). The cultivator consisted of six rigid tines, equipped with replaceable chisel points, staggered on a rugged tool bar, for each furrow there are three tines two in the front row, and third in the second row, at the center of the two front tines. The front lines were to loosen the sides of the furrows and to provide grooves for placement of fertilizers. The center tines were to loosen the middle of the furrows to provide more loose soil for coverage of fertilizers and reshaping of the ridges and furrows. The fertilizer applicator consisted of fertilizer hoper, metering devices, and delivery tubes. There were two main hoppers one for each row. Capacities of the compartment were $300 \mathrm{~kg}$ of fertilizer (PLATE 3). The metering devices were tractor-PTO driven mechanism. Fertilizer displacement (flow) was controllable through the setting of the drive linkages. Delivery tubes attached to the outlets of the metering devices and clamped to the backs of the front tines. The furrowing unit was a set of two moldboards, in addition to ridge and furrow reformation, furrowers were to cover fertilizer.

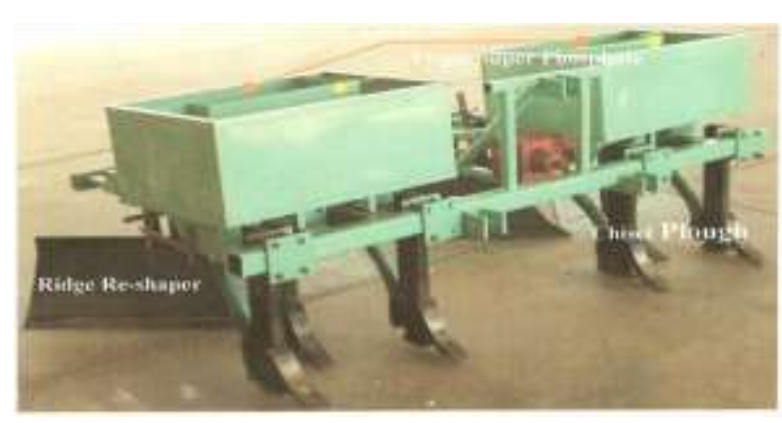

PLATE 4: Combined machine

TABLE 3: Specification of the developed combined Field cultivator

\begin{tabular}{ll}
\hline Parameter & Specification \\
\hline Type & Mounted two raw \\
Lifting & By tractor hydraulic \\
Overall height & $1460 \mathrm{~mm}$ \\
Length & $1665 \mathrm{~mm}$ \\
Width & $2480 \mathrm{~mm}$ \\
Hoper capacity & $300 \mathrm{~kg}$ of Fertilizer \\
Components & Fertilizer applicator, Rigid tine, \\
& Ridger \\
\hline
\end{tabular}

\section{Implements field performance}

(TABLE 4) shows a summary performance of the individual implements and combined machine in the experimental fields. It can be observed that the combined machine recorded similar effective field capacity $(2.57$ $\mathrm{fed} / \mathrm{h})$, as ridger and rigid tine $(2.54,2.5 \mathrm{fed} / \mathrm{h})$ respectively while the fertilizer applicator recorded 8.43 $\mathrm{fed} / \mathrm{h}$. Therefore, the combined machine in one path performs the three operations done by the three individual implements and almost in the same time. This is in line with the finding of [16]. Statistical analysis shows highly significant differences between treatments at $1 \%$ level (TABLE 5). (FIGURE 1) shows the comparison of effective field capacities for the combined machine and the three individual implements.

The total time taken by each implement in $(\mathrm{h} / \mathrm{fed})$ to complete the operation is given in (TABLE 4). The combined recorded the same time $(0.39 \mathrm{~h} /$ fed.) as for the two individual implements, ridger and rigid tine recorded $(0.40 \mathrm{~h} / \mathrm{fed})$, while the fertilizer applicator recorded 0.11 $\mathrm{h} / \mathrm{fed}$. When the time of the three implements added together $(0.91 \mathrm{~h} / \mathrm{fed}$.) and when compared with the time of combined (0.39), this gave a save of (57\%) of total time. This agrees with [17] and [9] who reported a saving of 55\% of the time.

TABLE 4: Average effective field capacity, fuel consumption, draw bar pull, draw bar power requirement and unit draft.

\begin{tabular}{ccccccc}
\hline Implement & $\begin{array}{c}\text { EFC } \\
\text { (Fed/hr) }\end{array}$ & $\begin{array}{c}\text { FC } \\
\text { (lit/Fed) }\end{array}$ & $\begin{array}{c}\text { Total time } \\
\text { (hr/fed) }\end{array}$ & $\begin{array}{c}\text { Db pull } \\
\text { (KN) }\end{array}$ & $\begin{array}{c}\text { Db power } \\
\text { (KW) }\end{array}$ & U d (KN/m) \\
\hline Combined & 2.57 & 2.41 & 0.39 & 7.51 & 12.51 & 3.02 \\
Ridger & 2.54 & 2.05 & 0.40 & 3.40 & 5.60 & 5.3 \\
Fertilizer App. & 8.43 & 0.45 & 0.11 & 0.50 & 0.83 & 0.17 \\
Rigid tine & 2.5 & 1.75 & 0.40 & 5.90 & 9.80 & 4.5 \\
\hline
\end{tabular}

EFC $=$ Field Capacity, $\mathrm{FC}=$ Fuel Consumption, $\mathrm{Db}=$ Draw bar, $\mathrm{Ud}=$ Unit Draft 


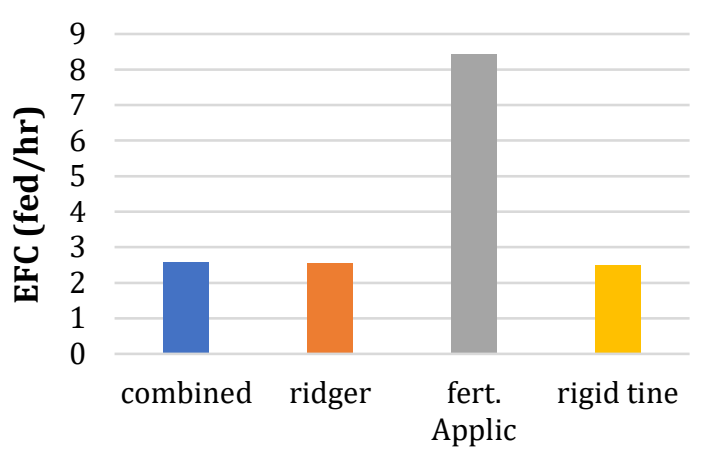

Implement type

FIGURE 1: Effect of implement type on EFC (Fed/hr)

The fuel consumption of the three individual implements when added together and compared with fuel consumption of the combined machine which carry out the three operations in one bath, it appears that the combined machine saves about (57\%) of fuel, which is above the rate mentioned by [11]. Statistical analysis showed highly significant differences between treatments at $1 \%$ level (TABLE 5). (FIGURE 2) shows fuel consumption of the combined machine as compared with the three individual implements.

It is clear that the combined implement recorded lower value of unit draft $(3.02 \mathrm{KN} / \mathrm{m})$, than Ridger $(5.3 \mathrm{KN} / \mathrm{m})$ and Rigid tine $(4.5 \mathrm{KN} / \mathrm{m})$, but the Fertilizer applicator recorded the lowest value of unit draft as $0.17 \mathrm{KN} / \mathrm{m}$, this could be due to lower draft value and bigger width of the implement. This is in line with the findings of [13] and report of [18].

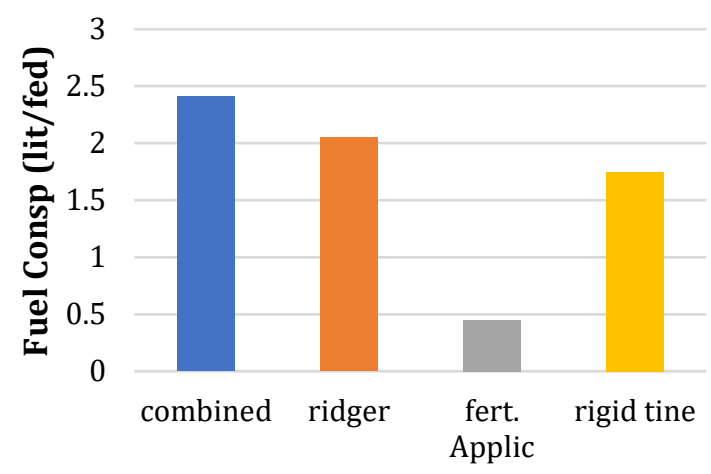

Implement type

FIGURE 2: Effect of implement type on fuel consumption rate in (lit/fed)

It can also observe that the combined machine recorded lower power requirement ( $12.51 \mathrm{KW})$ than the implements together which recorded (5.6 KW+0.80 kW+ 9.8 KW= 16.2 $\mathrm{kW})$. The higher power required the combined implement compared to the individual implements may be due to higher draft force exerted by the combined implement. [19] reported that draw bar power was increased as implement draft increased. The power required by the combined machine was less by $3.7 \mathrm{KW}$, compared to the individual implements together, this saved about $(23 \%)$ of power (FIGURE 3). This is in line with the findings of [6] and [20]. Statistical analysis showed significant differences between treatments at 5\% level (TABLE 5).

TABLE 5: Anova Table for different parameters

\begin{tabular}{cccc}
\hline & \multicolumn{3}{c}{ F value } \\
\cline { 2 - 4 } Parameters & f-cal. & $\mathbf{5 \%}$ & $\mathbf{1 \%}$ \\
\cline { 2 - 4 } & $44.5^{* *}$ & 8.62 & 26.5 \\
Field capacity & $1584^{* *}$ & 8.62 & 26.5 \\
Fuel consumption & $15.9^{*}$ & 8.62 & 26.5 \\
Drawbar pull & & & \\
\hline
\end{tabular}

* Significant at (0.05) level. ** Significant at (0.01) level.

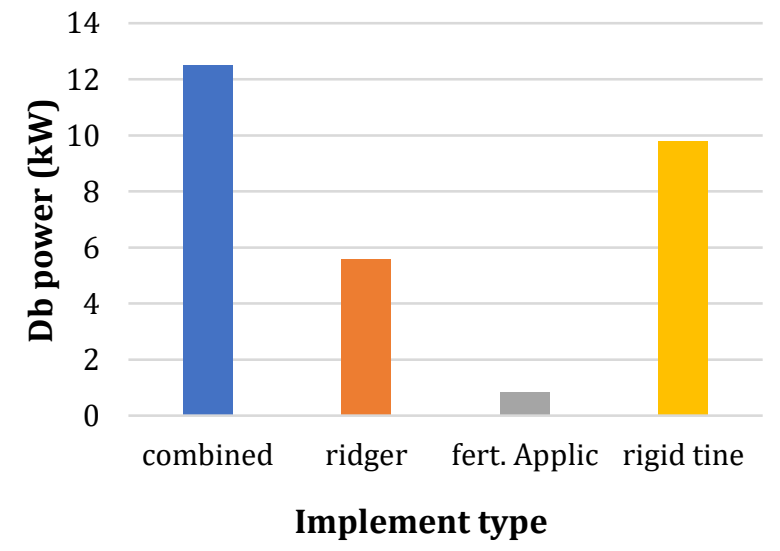

FIGURE 3: Effect of implement type on drawbar power $(\mathrm{kW})$ requirement

\section{CONCLUSION}

The following conclusion may be drawn from the present study:

The combined machine compared with individual implements (ridger, fertilizer app., rigid tine) was found reduced the power required by (23\%), total time by (57\%), fuel consumption by (57\%) and operate the same area done by the three implements together in the same period of time.

\section{REFERENCES}

[1] Hunt, D. (1995). Farm power and Machinery Management 9th ed. Iowa State University, Press Ames, Iowa 50014, USA.

[2] Black, Burn. (1984). Sugar Cane - Tropical Agriculture series, Longman Inc. New York.

[3] Lonsdale, John. (1977). Planting Depth and Seed Material for Establishing of Sugar Cane. Sao Paulo, Brazil.

[4] Irvine, J.E. and Benda, G.T. (1980). Sugar cane spacing. Proceeding of XVII Congress, Manila, Philippines 
[5] Mago (1983). Effects of earthing up on efficiency of sugar cane irrigation, American Sugarcane Seminar Journal of the school of the land: 185 - 197.

[6] Paterno, C. B. (1994). The multi-crop seeder. Journal of Agricultural Mechanization in Asia, Africa and Latin America. 25(3), 14-22

[7] Hajiahmad, A. and Javadi, A. Effect of a New Combined Implement for Reducing Secondary Tillage Operation. International Journal of Agriculture \& Biology 8(6): 724-727. 2006.

[8] Manjeet Prem, R. Swarnkar, D.K. Vyas, S.J. Pargi and B. C. Khodifad (2016). Combined Tillage Tools: A Review. Current Agriculture Research Journal 4(2), 179-185

[9] Kailappan, R., Vijayaraghavan, N.C., Swaminathan, K.P. and Muthan, G. (2001). Performance evaluation of the combination of tillage tools under field condition. Journal of Agricultural Mechanization in Asia, Africa and Latin America. 32(4), 9-12

[10] Peterson, M. (1983). The Chisel - Planter Minimum Tillage System, Transaction of ASAE, 26(6): 1412 1416.

[11] Sheruddin, B. (1981). Combination of rotary tiller and pneumatic seeder. Agricultural mechanization in Asia, Africa and Latin America, 12(4): 13-15.

[12] Abdalla, Y.A. (2000). Development and evaluation of a combined ridger-planter implement. M.Sc. thesis, Faculty of Agriculture, University of Khartoum, Sudan

[13] Dahab, M.H., Mohamed, H. I. and Elramlawi, H. R. (2007). A combined chisel- ridger implement for economizing power under heavy clay soils. Journal of Science and Technology (SUST). 8(1), 162-172
[14] Manjeet Prem, Prem Ranjan, K.L. Dabhi, A.V. Baria and Pema T. Lepcha (2017). Use of Different Tillage Tools for Minimizing Number of Passes in Secondary Tillage Operations. Int.J.Curr.Microbiol.App.Sci 6(12): 3109-3116

[15] Raheman, H. and Roul, A.K. (2013). Combination Tillage Implement for High Horse Power 2WD Tractors. Agricultural Mechanization in Asia, Africa, and Latin America 44(3): 75-79.

[16] Dhakane, A. D, Turbatmath, P.A. and Pandey, V. (2010). The field performance evaluation of tractor operated combination tillage implements. International Journal of Agricultural Engineering 3(1): 138-143.

[17] Maheshwari, T.K., Thakur, T.C. and Varshney, B.P. (2004). Comparative performance of spiked clod crusher and planker as combination tillage tools with tractor drawn cultivator under different soil conditions. New Agriculturist 15 (1/2): 13-17.

[18] Sahu, R. K. and Hifjur, R. (2005). An approach for draft prediction of combination tillage implements in sandy clay loam soil. Soil \& Tillage Research 90: 145155

[19] Belal, M.M and Dahab, M.H. (1997). Effect of Soil Condition on a two-wheel drive tractor performance, using three types of tillage implements. University of Khartoum, Journal of Agricultural Science 5(2): 1-22.

[20] Manian, R., Kathirvel, K. and Nagaiyan, V. (1999) Development and evaluation of combination tillagebed furrow-former. AMA, Agricultural Mechanization in Asia, Africa and Latin America 30(4): 22-29. 